\title{
Role of Police in Respecting Crimes on Prisoners Who Get Asimilation \& Conditioned Delivery Due to Plague of Covid-19
}

\author{
Lilik Purwoko ${ }^{*}$ and Siti Rodhiyah Dwi Istinah ${ }^{* *}$ ) \\ ${ }^{*}$ Student of Master of Law, Faculty of Law, Universitas Islam Sultan Agung \\ Semarang, E-mail: lilikp mh35@std.unissula.ac.id \\ ${ }^{* *)}$ Faculty of Law, Universitas Islam Sultan Agung Semarang,
}

\begin{abstract}
The purpose of this study was to determine and analyze the role of the Police in tackling crimes by convicts who received assimilation and parole due to the Covid-19 virus outbreak and the obstacles and solutions of the Police in overcoming crimes by inmates who received assimilation and parole due to the Covid-19 virus outbreak. Used in this research is an empirical juridical approach. This type of research is descriptive analytical, data collection methods used are primary data (interviews) and secondary data (literature review). The data analysis was done qualitatively. The results of the research found that the role of the Police in tackling crimes by inmates who received assimilation and parole due to the Covid-19 virus outbreak has an important role. Which was carried out by the Police in minimizing crimes committed by inmates who received assimilation due to the impact of Covid-19, namely preventive efforts to conduct patrols by forming a new eagle team, as well as repressive efforts to provide strict punishment to inmates who committed crimes again after assimilation. The obstacles faced by the Police in overcoming crimes by inmates who receive assimilation and parole due to the Covid-19 virus outbreak include, among others, that not all criminals are domiciled in the city of Semarang, the number of personnel is not proportional to the number of prisoners who receive assimilation and parole due to the virus outbreak. Covid19 , the National Police and the Police have never received a copy of the trial verdict from the court,

Keywords: Countermeasures; Assimilation; Parole; Covid-19.
\end{abstract}

\section{Introduction}

The policy of releasing prisoners in an effort to reduce the rate of spread of the corona virus is the authority of the Indonesian Government through the Ministry of Law and Human Rights which is based on the government's concern about the spread of the corona virus in prisons. The government's decision to release these prisoners is based on Regulation of the Minister of Law and Human Rights Number 10 of 2020 concerning the Conditions for Providing Assimilation and Integration Rights for Prisoners and Children and Decree of the Minister of Law and Human Rights No. M.HH19.PK.01.04.04 / 2020 concerning the Release and Release of Prisoners and Children 
through Assimilation and Integration in the Context of Preventing and Combating the Spread of Covid-19. ${ }^{1}$

The release of prisoners in order to reduce the rate of transmission of Covid-19 cannot be denied if it still causes controversy in the community. The government decision invited questions from the public regarding the release of prisoners in relation to the safety and comfort of citizens, even though prisoners who had been released due to the assimilation and integration program had gone through the behavior assessment stage. The public doubts that efforts to release prisoners are the right step in preventing the spread and transmission of Covid-19.

The police are the first institution that must be passed in the criminal justice process, therefore the police apparatus has the authority to carry out investigations, investigations, detention, confiscation, until a crime that is suspected to have been committed is found. In accordance with the provisions of Article 13 of Act No. 2 of 2002 concerning the Police, the main task of the Police is to maintain security and public order, enforce the law and provide protection, protection and services to the community. In relation to the implementation of these tasks, it is necessary to have the role of the elements that carry out the main tasks. ${ }^{2}$

Criminal acts committed by assimilated prisoners have occurred in Semarang City. Based on the Republika.co.id page, the Semarang Police arrested a prisoner who underwent assimilation while distributing a type of crystal methamphetamine-type narcotics in Semarang City. The Head of the Semarang Police Narcotics Detective, Commissioner R Sihombing, said that the suspect M Purnomo (38) was a narcotics case recidivist who previously served a sentence at the Sragen prison. ${ }^{3}$

In addition, it was also found that the ex-convicts were arrested for acting up by repeating criminal acts. Head of Public Relations of the Central Java Regional Police, Kombes Iskandar F Sutisna, said that in Central Java there were 1,770 prisoners who had entered the assimilation program and had returned to society. Of the assimilated convicts, some have been caught again committing crimes or criminal acts in several Polres, namely Semarang, Jepara, Sukoharjo, Kebumen, Sragen, Banyumas, Surakarta with a total of 10 suspects. ${ }^{4}$

This case proves that prisoners can act again which indicates that the behavior assessment before they are released and allowed to integrate into society is less effective. The government at that time could not guarantee that if the prisoner would not repeat his crime, then what the government could guarantee was the supervision and action of officers who were always on guard to overcome if the prisoners

\footnotetext{
${ }^{1}$ Trias Palupi Kurnianingrum. Kontroversi Pembebasan Narapidana Di Tengah Pandemi Covid 19, Info Singkat. Vol. XII No. 8 / II / Puslit / April 2020. p. 1-2

2 Eddy Santoso, Sri Endah Wahyuningsih, Umar Ma'ruf, Peran Kepolisian Dalam Sistem Peradilan Pidana Terpadu Terhadap Penanggulangan Tindak Pidana Perjudian, Jurnal Daulat Hukum, Vol. 1. No. 1 Maret 2018, url: http://jurnal.unissula.ac.id/index.php/RH/article/view/2632. p. 186

3 Nidia Zuraya. Napi Asimilasi di Semarang Diringkus Saat Edarkan Narkotika, https://republika.co.id/berita/q9jjiq383/napi-asimilasi-di-semarang-diringkus-saat-edarkan-narkotika, Accessed on 30 September 2020.

${ }^{4}$ Angling Adhitya Purbaya. Dirumahkan Malah Berulah, 10 Napi di Jateng Nyolong Hingga Cabuli Bocah. https://news.detik.com/berita-jawa-tengah/d-4984321/dirumahkan-malah-berulah-10-napi-di-jatengnyolong-hingga-cabuli-bocah. Accessed on 30 September 2020.
} 
committed their criminal acts again after these convicts were returned to society. The role of the Criminal Investigation Unit at this time is expected to be able to reveal cases of crimes that occur in the community, especially those committed by ex-convicts who received assimilation due to the Covid-19 outbreak.

The objectives to be achieved in this study are: to find out and analyze the role of the Semarang Police Criminal Investigation Unit in tackling crimes by convicts who receive assimilation and parole due to the Covid-19 virus outbreak, and to find out and analyze the obstacles and solutions of the Semarang Police Satreskrim in tackling crimes by convicts who receive assimilation and parole due to the virus outbreak Covid- 19 .

\section{Research methods}

The approach method used in this research is a juridical empirical approach or in other words, sociological juridical. The empirical approach is to identify and conceptualize law as real and functional social institutions in real life systems. ${ }^{5}$ This type of research is descriptive analytical, because specifically this study aims to describe the problems in this study, ${ }^{6}$ namely the role of the police in tackling crimes by inmates who receive assimilation and parole due to the Covid-19 virus outbreak. Types of data used are primary and secondary data. Data collection methods used primary data, namely by interview and secondary data reviewing documents related to research. The analytical method that researchers use is qualitative data analysis. This data analysis was carried out by the researcher carefully guided by the type and purpose of the research conducted. This data analysis is described in the form of sentences which are then regularly and systematically in the form of legal writing.

\section{Results and Discussion}

\subsection{The Role of the Police in Handling Crime by Inmates Receiving Assimilation and Parole Due to the Covid-19 Virus Outbreak}

The police play an important role in tackling crimes committed by assimilated inmates during the Covid-19 pandemic. $^{7}$ The police, as protectors and law enforcers in the structure of community life, have a special responsibility to maintain public order and to handle and resolve any actions, both crimes and violations that occur in each region. ${ }^{8}$ The role of the police according to Act No 2 of 2002 concerning the State Police of the Republic of Indonesia is contained in Article 5 paragraph 1 which reads "The Indonesian National Police is a state instrument that plays a role in maintaining security and public order, enforcing the law, and providing protection, protection, and service to the community in the framework of maintaining domestic security". ${ }^{9}$ The

\footnotetext{
${ }^{5}$ Soekanto, Soerjono. (2007). Perihal Penelitian Hukum. Jakarta: UI Press. p. 51.

6 Soemitro, Ronny Hanitijo. (1988). Metodologi Penelitian Hukum dan Jurimetri. Jakarta: Ghalia Indonesia. p. 52.

${ }^{7}$ Mohamad Anwar. Asimilasi dan Peningkatan Kriminalitas Di Tengah Pembatasan Sosial Berskala Besar Pandemi Corona, 'Adalah' Buletin Hukum \& Keadilan, Volume 4 Nomor 1 (2020). url: http://journal.uinjkt.ac.id/index.php/adalah/article/download/15504/7263. p. 107.

${ }^{8}$ Rahardjo, Sajipto. (2012). Ilmu Hukum. Bandung: Citra Aditya Bakti. p. 91

${ }^{9}$ Utomo, Warsito. (2005). Hukum Kopolisian di Indonesia. Jakarta: Prestasi Pustaka. p. 37
} 
police have an important role in the prevention and handling of crime, because the police are at the forefront of law enforcement and eradicating various criminal acts that occur in the community. ${ }^{10}$

The first stage, as many as 351 convict in a detention center or correctional facility at Central Java released in anticipation of spread Corona virus or Covid-19. There are several conditions that must be met by prisoners who are released, including twothirds of the sentence until 31 December 2020, not included in Government Regulation Number 99 of 2012 concerning Terms and Procedures for the Implementation of the Rights of Prisoners and assimilation carried out at home. As the capital city of Central Java, Semarang is usually the destination of convicts who get assimilated to look for work or do other things that are deviant in society. Reporting from jateng.tribunnews.com, there are two assimilating prisoner in Semarang, again acting out drugs in the form of crystal methamphetamine were each caught carrying a package of crystal methamphetamine. Special prisoners in drug criminal cases who get assimilation had actually been monitored unconsciously from the first day of release in the Polrestabes area of Semarang, members have been deployed to monitor drug convicts who have just been released for fear that they could act up again. However, this countermeasure is still lacking, which is an important task for the Semarang Police Unit to overcome irregularities committed by assimilated prisoners in the jurisdiction of Semarang.

In addition, an interview conducted by the Semarang Police Unit for Criminal Investigation stated that out of 17 Sub-Police Office in the Semarang Police, prisoners who received assimilation and parole due to the Covid-19 pandemic outbreak returned to committing crimes and were re-processed by Criminal Investigators from the East Semarang Police. ${ }^{11}$

The role of the police in society is partners who need each other, we agree that the police or police officers in this country have a function in the structure of community life as protectors of the community, as enforcing the law, namely having a special responsibility to maintain public order and handle crime, both in the form of actions against criminals and in the form of crime prevention efforts so that members of the public can live and work in a safe and secure condition. ${ }^{12}$

Efforts to cope are defined as activities to prevent. The impact of assimilation carried out by the government on prisoners is that the occurrence of crimes is very disturbing and disturbing the community. Completely eliminating the crimes committed by assimilated prisoners is something that is difficult and arguably impossible, because as long as there are humans as social beings who have different interests, during that time there must be crimes. ${ }^{13}$ Based on the research results, it is known that the efforts made

\footnotetext{
${ }^{10}$ Abdussalam, R. (2014). Penegak Hukum Di Lapangan Oleh Polri. Jakarta: Dinas Hukum Polri. p. 21.

${ }^{11}$ Interview conducted with AKP Esti Handayani $\mathrm{SH}, \mathrm{MH}$ as well as the Head of the Criminal Investigation Unit of the Semarang Police on November 13, 2020.

12 Tasaripa, K. (2013). Tugas dan Fungsi Kepolisian Dalam Perannya Sebagai Penegak Hukum Menurut Undang-Undang Nomor 2 Tahun 2002 Tentang Kepolisian. Jurnal Ilmu Hukum Legal Opinion,Vol.1, (No.2). p. 1-9.

13 Jufri, Ely Alawiyah. (2017). Pelaksanaan Asimilasi Narapidana di Lembaga Pemasyarakatan Terbuka Jakarta, ADIL: Jurnal Hukum Vol. 8 No.1. url.https://media.neliti.com/media/publications/217392pelimplementation-asimilation-narapidana-di-lemb.pdf. p.7.
} 
by the Police to minimize crimes committed by inmates who are assimilated due to the impact of Covid-19 consist of pre-emptive, preventive and repressive efforts. ${ }^{14}$ Each of these efforts is described as follows:

\subsubsection{Preventive measures}

Preventive measures are a follow-up to pre-emptive efforts that are still at the level of prevention. In preventive efforts, the emphasis is on eliminating the opportunity to commit crimes. According to the Police, the police stated that there were several things done by the police to prevent crimes committed by inmates who received assimilation and parole due to the Covid-19 virus outbreak, namely the formation of the New Eagle team to patrol the Semarang area. The New Elang team consists of 2 teams, where each team consists of 13 members ( 1 officer and 12 non-commissioned officers). The New Elang team is on duty based on a warrant which is signed by the Head of Police of the Republic of Indonesia every month. In charge of supporting tools and facilities for Team New Elang are 10 2-wheeled motorbikes, 1 Avanza car, 10 bullet-proof vests, 10 helmets,

The New Elang Team is tasked with carrying out patrols in the area where the police are prone to crime at certain hours. The determination of certain vulnerable hours is based on the results of the analysis and evaluation carried out every month by the Chief of Police of the Police. Evaluation analysis in each Polsek includes prominent cases, critical hours, hot days, hot spots, and determining how to act.

Then the results of the Analysis and Evaluation of the Satreskrim Kaurbinops were conveyed as guidelines and orders to the New Eagle Team in conducting patrols every night, so that they were more focused, except when the patrol occurred an event that was urgent and prominent, then the implementation of the patrol could change related to the situation and conditions on the ground. The New Elang team patrol also synergized and intersected with the Resmob Team in each Police.

\section{Repressive measures}

Repressive measures are intended to punish the perpetrators of crimes according to their actions and to correct them again so that they are aware that their actions are illegal and detrimental to society. In connection with the prosecution carried out against the perpetrator, the police have taken legal action in the form of arrest, detention and the process of transferring cases to court to convicts who have committed crimes again. ${ }^{15}$ If proven guilty and then convicted by a judge, then to serve his sentence, a correctional institution will carry out re-training. For example, the New Elang team patrols the jurisdiction of the West Semarang Police, it will meet with the West Semarang Police Resmob Team to coordinate and communicate with each other. In addition, Kasatreskrim ordered the Head of Criminal Investigation to always be sensitive and pay close attention to the Kamtibmas situation that occurred in their respective areas. By increasing the patrol of the official team, including monitoring the activities of the prisoners in the respective police areas and coordinating with the head of the RT / RW where the prisoners live.

\footnotetext{
${ }^{14}$ Meliala, Adrianus. (2006). Problema Reformasi Polri. Jakarta: Trio Repro. p. 30.

15 Arief, Barda Nawawi. (2008). Masalah Penegakan Hukum dan Kebijakan Hukum. Pidana dalam Penanggulangan Kejahatan. Jakarta: Kencana. p. 43.
} 


\subsection{Police Constraints and Solutions in Tackling Crime by Prisoners who Receive Assimilation and Parole Due to the Covid-19 Outbreak}

Based on an interview conducted by the Semarang Police Satreskrim, the obstacles faced by the Semarang Police Satreskrim in overcoming crimes by inmates who received assimilation and parole due to the Covid-19 virus outbreak, among others, are: ${ }^{16}$

- Not all criminals are domiciled in the city of Semarang, making it difficult for the Criminal Investigation Unit of the Police to carry out monitoring of the activities of prisoners who receive assimilation and parole.

- The number of personnel is not proportional to the number of prisoners who have received assimilation and parole due to the Covid-19 virus outbreak. The convicts that are monitored are not only free prisoners in Semarang prison but throughout Central Java because Semarang is a big city that can make prisoners find work or do other things. Who deviated in the city.

- The Satreskrim Polrestabes and Polsek have never received a copy of the trial verdict from the court. Even though it has been regulated in Article 226 of the Criminal Procedure Code. This is due to the lack of cooperation between the police and the courts.

- The community does not participate, to show its effectiveness the police must have a target. Every police activity for the prevention and prevention of crime must be evaluated. Since the police can't do everything, they have to negotiate with the community about what they are going to do. It is necessary to make crime prevention by the police. It is also important as a crime prevention technique, as consultation from the police can educate the public about the causal reality of crime and can enlist them in meaningful prevention efforts. Lack of public knowledge about the importance of security. The community should not only leave the task of community service to the police, but the community must also play a role in maintaining security. The community has a very big role in crime prevention efforts where the police really need the entry of reports from the public regarding suspicious activities or people that will lead to or commit crimes. Many people are reluctant to report or provide information about going to or being or after a crime has occurred and are more likely to avoid dealing with the police as much as possible. They feel that the police only interfere with their activities, especially when they have to go to the police station to provide information. The number of obstacles and actions that deviate from the role and function of the police in carrying out their duties has resulted in the community's lack of trust in the police.

In dealing with these obstacles, the solution provided by the Semarang Police Unit in the process of overcoming crimes by inmates who receive assimilation and parole due to the Covid-19 virus outbreak are: ${ }^{17}$

\footnotetext{
16 Interview conducted with AKP Esti Handayani SH, MH as well as Kaurbinops Satreskrim Semarang Police on November 13, 2020

17 Interview conducted with AKP Esti Handayani SH, MH as well as Kaurbinops Satreskrim Semarang Police on November 13, 2020
} 
- In every investigation process (Case Files), the Semarang Police and Police Investigators must include an address other than the one listed on the suspect's ID card.

- Building networks and synergistic cooperation with the District Court, especially with Court Clerks so that copies of the verdict can reach investigators so that it makes it easier to monitor when prisoners leave prison.

- Appealing to the public to be more vigilant so that they do not become victims of crime when they return home at night, so you should not be alone and try to pass a safe route. In addition, we urge the public to report when or see crimes.

\section{Closing}

Based on the results of the research and discussion above, it can be concluded that the role of the police in tackling crimes by inmates who receive assimilation and parole due to the Covid-19 virus outbreak has an important role which was carried out by the police in minimizing crimes committed by inmates who received assimilation due to the impact of Covid-19, namely preventive efforts to carry out patrols with the formation of a new eagle team, as well as repressive efforts to provide strict punishment to inmates who committed crimes again after assimilation. The obstacles faced by the police in overcoming crimes by convicts who receive assimilation and parole due to the Covid-19 virus outbreak include not all criminals domiciled in the city of Semarang, Based on the above conclusions, the authors suggest that all levels of society without exception are urged to always participate in prevention efforts. Without the support of the community, the efforts of the police will not produce maximum results. In addition, it is hoped that the family will pay attention to inmates who receive assimilation. This is very important because they can control them from committing crimes again. In addition, the police have further strengthened information relations within their ranks at the unit, police, police, and even regional police to facilitate investigations, as well as to further improve supervision and monitoring of each recidivist and his network.

\section{References}

\section{Scientific Journal and Internet:}

[1] Angling Adhitya Purbaya. Dirumahkan Malah Berulah, 10 Napi di Jateng Nyolong Hingga Cabuli Bocah. https://news.detik.com/berita-jawa-tengah/d4984321/dirumahkan-malah-berulah-10-napi-di-jateng-nyolong-hingga-cabulibocah. Accessed on 30 September 2020.

[2] Eddy Santoso, Sri Endah Wahyuningsih, Umar Ma'ruf, Peran Kepolisian Dalam Sistem Peradilan Pidana Terpadu Terhadap Penanggulangan Tindak Pidana Perjudian, Jurnal Daulat Hukum, Vol. 1. No. 1 Maret 2018, url: http://jurnal.unissula.ac.id/index.php/RH/article/view/2632.

[3] Jufri, Ely Alawiyah. (2017). Pelaksanaan Asimilasi Narapidana di Lembaga Pemasyarakatan Terbuka Jakarta, ADIL: Jurnal Hukum Vol. 8 No.1. url.https://media.neliti.com/media/publications/217392-pelimplementationasimilation-narapidana-di-lemb.pdf. 
[4] Mohamad Anwar. Asimilasi dan Peningkatan Kriminalitas Di Tengah Pembatasan Sosial Berskala Besar Pandemi Corona, 'Adalah' Buletin Hukum \& Keadilan, $\begin{array}{lllll}\text { Volume } & 4 & \text { Nomor } & 1 & \text { (2020). }\end{array}$ http://journal.uinjkt.ac.id/index.php/adalah/article/download/15504/7263.

[5] Nidia Zuraya. Napi Asimilasi di Semarang Diringkus Saat Edarkan Narkotika, https://republika.co.id/berita/q9jjiq383/napi-asimilasi-di-semarang-diringkussaat-edarkan-narkotika, Accessed on 30 September 2020.

[6] Tasaripa, K. (2013). Tugas dan Fungsi Kepolisian Dalam Perannya Sebagai Penegak Hukum Menurut Undang-Undang Nomor 2 Tahun 2002 Tentang Kepolisian. Jurnal Ilmu Hukum Legal Opinion, Vol.1, (No.2).

\section{Books:}

[1] Abdussalam, R. (2014). Penegak Hukum Di Lapangan Oleh Polri. Jakarta: Dinas Hukum Polri.

[2] Arief, Barda Nawawi. (2008). Masalah Penegakan Hukum dan Kebijakan Hukum. Pidana dalam Penanggulangan Kejahatan. Jakarta: Kencana.

[3] Meliala, Adrianus. (2006). Problema Reformasi Polri. Jakarta: Trio Repro.

[4] Rahardjo, Sajipto. (2012). Ilmu Hukum. Bandung: Citra Aditya Bakti.

[5] Soekanto, Soerjono. (2007). Perihal Penelitian Hukum. Jakarta: UI Press.

[6] Soemitro, Ronny Hanitijo. (1988). Metodologi Penelitian Hukum dan Jurimetri. Jakarta: Ghalia Indonesia

[7] Utomo, Warsito. (2005). Hukum Kopolisian di Indonesia. Jakarta: Prestasi Pustaka.

Etc:

[1] Interview conducted with AKP Esti Handayani $\mathrm{SH}, \mathrm{MH}$ as well as the Head of the Criminal Investigation Unit of the Semarang Police on November 13, 2020.

[2] Trias Palupi Kurnianingrum. Kontroversi Pembebasan Narapidana Di Tengah Pandemi Covid-19, Info Singkat. Vol. XII No. 8 / II / Puslit / April 2020. 